\title{
The Concordance of Three Diagnostic Test for Malassezia folliculitis using Potassium Hydroxide 20\% + Blue-Black Parker Ink, May Grunwald Giemsa, and Potassium Hydroxide 10\% + Chicago Sky Blue
}

\author{
Dyatiara Devy Rahadiyanti, Damayanti, Dwi Murtiastutik, Sawitri, Afif Nurul Hidayati, \\ Evy Ervianti \\ Departement of Dermatology and Venereology \\ Faculty of Medicine Universitas Airlangga/Dr. Soetomo General Academic Teaching Hospital \\ Surabaya
}

\begin{abstract}
Background: Malassezia folliculitis is a pilosebaceous follicular infection disease caused by Malassezia species. There are many misdiagnosed Malassezia folliculitis cases, causing the maladministration of therapy. A routine diagnostic test performed for Malassezia folliculitis cases is the identification of fungal elements (spore) with a microscope using potassium hydroxide, but it has several weaknesses. Purpose: To evaluate the suitability of Malassezia folliculitis diagnostic test using Potassium Hydroxide 20\% + Blue-Black Parker Ink, May Grunwald Giemsa, and Potassium Hydroxide 10\% + Chicago Sky Blue. Methods: Analytic observational study conducted in the Dermatomycology Division of Dermatology and Venereology outpatient clinic, Dr. Soetomo General Hospital Surabaya. The samples were thirty patients with clinical features of Malassezia folliculitis. The research material was obtained from the body as many as three pieces of papulomoluscoid lesion extracted. The material obtained was then divided into three glass objects for Potassium Hydroxide 20\% + Blue-Black Parker Ink, May Grunwald Giemsa, and Potassium Hydroxide 10\% + Chicago Sky Blue staining. Result: The identification of spores using Potassium Hydroxide 20\% + Blue-Black Parker Ink was 90\%, May Grunwald Giemsa was 90\%, and Potassium Hydroxide $10 \%+$ Chicago Sky Blue was $93 \%$ with a value of $\kappa=0.348$ and $\mathrm{p}=0.051$. The diagnostic values of May Grunwald Giemsa and Potassium Hydroxide 10\% + Chicago Sky Blue were 96.6\% sensitivity, 33.3\% specificity, 92.9\% Positive Predictive Value, and $50 \%$ Negative Predictive Value. Conclusions: There was no significant concordance between May Grunwald Giemsa and Potassium Hydroxide 10\% + Chicago Sky Blue with Potassium Hydroxide 20\% + Blue-Black Parker Ink in establishing the diagnosis of Malassezia folliculitis. Potassium Hydroxide 20\% + Blue-Black Parker Ink is still needed as a routine examination in cases with clinical features of Malassezia folliculitis.
\end{abstract}

Keywords: Malassezia folliculitis, Potassium hydroxide, Blue-Black Parker Ink, May Grunwald Giemsa, Chicago Sky Blue.

Correspondence address: Evy Ervianti, Department of Dermatology and Venereology, Faculty of Medicine, Universitas Airlangga, Dr. Soetomo General Academic Teaching Hospital, Jl. Mayjen Prof. Dr. Moestopo No. 6-8 Surabaya 60131, Indonesia. Phone: (031) 5501609, e-mail: evy_if@yahoo.co.id.

\section{INTRODUCTION}

Malassezia folliculitis (MF) is a pilosebaceous follicular infection caused by Malassezia organism. ${ }^{1-4}$ Malassezia sp infects follicular ostium, middle, and deep segments of hair follicles. The most common Malassezia sp is Malassezia furfur. Malassezia organism is a lipophilic fungus and is a normal flora in $75-98 \%$ of healthy people. Colonization can develop a peak when a teenager or young adult experiences the development of sebaceous gland activity. ${ }^{5}$ Some conditions such as diabetes mellitus, infection with Human Immunodeficiency Virus (HIV), pregnancy, cancer with epidermal growth factor inhibitor therapy, therapy with oral antibiotics, and use of corticosteroids or other immunosuppressant drugs can trigger this disease. A high humidity environment is also the contributing factor in increasing the incidence of MF disease. Hot weather can increase the rate of sebum secretion on the skin, promoting the ideal environment for Malassezia to breed. ${ }^{6}$ Respective to the geographical conditions of Indonesia, which is a tropical country, the high temperature and humidity will facilitate the fungal growth; therefore fungal infections are often found in Indonesia. ${ }^{5}$ Other predisposing factors show that antibiotics may cause MF. Sharquie et al. mentioned that antibiotics were the second most common worsening factor in cases with MF amounted to $37.7 \%{ }^{7}$

The incidence of MF in the Dermatology and Venereology Outpatient clinic of Dr. Soetomo General Hospital Surabaya from 2011 to 2015 increased with a slight decrease in 2014. In contrast, research by Primasari PI found the incidence of MF decreased in 2017 by 27 patients (12.2\%). The incidence in 2016 
was found sufficiently high, with 65 cases (26\%). Research by Pravitasari in the Mycology Division of Dermatology and Venereology outpatient clinic of Dr.Soetomo Surabaya Hospital from October 2014 to January 2015 showed that the age group of the most 36 MF patients was 15-24 years. A study in Turkey conducted by Durdu and his colleagues found that there were $4 \%$ MF cases of total dermatology clinic admission with an average age of 26 years. ${ }^{8}$ A study in America by Brea and friends in 2010-2015 involving 110 patients showed that the average MF patient was 15 years old. ${ }^{9}$

The diagnosis is MF includes history taking, physical examination, direct microscopic examination, and biopsy for doubtful cases. Clinical symptoms of MF in the form of follicular papules and papulopustules $2-4 \mathrm{~mm}$ in size with perifollicular erythema and itchy on predilection area, especially on the trunk such as back, chest, and upper arms. These clinical symptoms are difficult to distinguish from acne vulgaris or bacterial folliculitis thus several tests are required to confirm the diagnosis. ${ }^{5}$ A case report showed several misdiagnosed cases with clinical pictures similar to MF, resulting in therapeutic errors. This indicates that MF cases are often misdiagnosed with acne vulgaris or other differential diagnosis, causing further therapeutic errors. ${ }^{10}$

A routine diagnostic test performed for MF cases is the identification of fungal elements (spores) under a microscope using $20 \%$ potassium hydroxide $(\mathrm{KOH})$, which is a fast and low-cost method. The weakness of $\mathrm{KOH}$ is the presence of artifacts that are difficult to distinguish from fungal elements, so expert is needed to interpret the results. It still can cause misdiagnosis or delayed treatment, so that an easier and more precise diagnostic tool is needed in diagnosing MF, but studies on alternative staining in MF cases are still rarely encountered. ${ }^{2}$

May Grunwald Giemsa is a dye that is often used for cytological examination. Research conducted by Durdu et al. on May Grunwald Giemsa (MGG) staining found a high positive result (100\%) compared to $\mathrm{KOH}$ $(81.06 \%)$. MGG staining is a mixture of two colors, consisting of May Grunwald solution and Giemsa solution. May Grunwald Giemsa provides sharper and purplish-pink coloring. This staining can be used to assess diagnostics other than MF cases such as bacillary formation in acne vulgaris; acantholytic cell features in patients with pemphigus vulgaris; foreign body-type giant cell images in patients with cystic lesions in the jaw; and eosinophil taken from speciments patients with very itching complaints. ${ }^{17}$

Chicago Sky Blue (CSB) is a new coloring method that uses a mixture of $\mathrm{KOH}$ solution with a
Chicago Sky Blue dye in order to clarify the image of spores or hyphae. The smear contains $1 \%$ CSB $6 \%$ and is used together with $\mathrm{KOH}$ as a clearing agent. This smear distinguishes the blue color of the fungal filament from its pale or purple base. ${ }^{15}$ CSB $6 \%$ is added to the $30 \% \mathrm{KOH}$ solution to produce certain coloring agents, such as fungi, especially from the genus Trichophyton, Candida, and Malassezia. ${ }^{19}$ Malassezia will provide a contrast blue color both on hyphae and spores against a pale pink background. ${ }^{19}$ Direct microscopic examination with CSB staining is a fast, simple, and easy new method. It produces good color contrast for easier fungal element observation even by non-experienced examiners; and after 24 hours, the reading will be clearer. ${ }^{20}$

This study was carried out to identify spores with $20 \% \mathrm{KOH}$ staining + Parker $^{\mathrm{TM}}$ blue-black ink, MGG, and $10 \% \mathrm{KOH}+\mathrm{CSB}$ in patients with clinical features of MF in the Dermatomycology Division of the Dermatology and venereology Outpatient clinic Dr. Soetomo Surabaya. This research is expected to provide new easier, quicker, and more precise alternatives in diagnosing MF.

\section{METHODS}

This was a cross-sectional analytic observational study aimed to evaluate the suitability of MF diagnostic examination using $20 \%$ potassium hydroxide $(\mathrm{KOH})+$ Parker $^{\mathrm{TM}}$ blue-black ink, MGG, and CSB in the Dermatomycology Division of Dermatology and Venereology Outpatient Clinic of Dr. Soetomo General Hospital Surabaya. The inclusion criteria of this study were new patients with clinical features of MF, aged 12-45 years old, moderate itching complaints, and willing to participate in the research (sign informed consent). The exclusion criterion for this study was a history of using topical and oral antifungal in the last three days. Patients who met the inclusion and exclusion criteria were included in the study, which was conducted in 3 months from May 2019 to August 2019.

The study began with an examination of patients of Dr. Soetomo Hospital Surabaya. History taking, the clinical examination, and Wood's lamp examination were performed. Should a patient be willing to participate, and he/she meets the research criteria, research purposes and benefits were then conveyed. Patients who had verbally affirmed the research participation were then asked to read and sign the informed consent. Once the informed consent signed, samples collection of 3 parts of the papulomoluscoid lesion was done using comedone extractor. The materials obtained were then divided into three glass objects for three stainings i.e. $20 \% \mathrm{KOH}+$ Parker $^{\mathrm{TM}}$ 
blue black ink, MGG and $\mathrm{KOH} 10 \%+\mathrm{CSB}$. On examination using $20 \% \mathrm{KOH}+$ Parker $^{\mathrm{TM}}$ blue black ink, we used spore load grading from JacintoJamora that were positive if visible fungal elements in the form of spores with a clear base showing grading > +2 . Grade 3, if found 7-12 spores in groups or 13-20 scattered spores and grade 4 if found $>12$ spores in groups or $>20$ scattered spores per field of view. Under microscopic examination using MGG staining, positive result showed pinkish purple spores and bluish-colored when using CSB staining against a pale pink or purple background. In all three examinations this is negative if no spores on the microscope examination.

This study has been approved by the ethics committee of Dr. Soetomo General Hospital Surabaya. The collected data is tabulated in $2 \times 2$ tables and graphs.

\section{RESULTS}

This study involved 30 subjects who met the inclusion and exclusion criteria with the consecutive sampling method. All eligible study subjects were asked to sign the informed consent and medical action approval sheets. The data of research subjects were recorded, and skin scraping results were examined under a microscope using three stainings namely $20 \%$ Potassium Hydroxide $(\mathrm{KOH})+$ blue-black Parker ${ }^{\mathrm{TM}}$ ink, May-Grunwald-Giemsa (MGG), and $10 \% \mathrm{KOH}+$ Chicago Sky Blue (CSB).

The baseline data of subjects are presented in Table 1. This study involved more male subjects (73.3\%) than female subjects (26.7\%). The majority of the age range of participants was $17-25$ years $(63.3 \%)$, with the youngest participant aged 13 years old, and the oldest participant aged 45 years old. The mean age was $23.67 \pm 7.14$ years.

Table 2 presents that there were three illness predilections with moderate itch occurred on the back, the back and chest, the back, chest, and upper arm, each of which contributed $30 \%$. There was one patient (3.3\%) who had received a topical antifungal treatment, and the rest 29 patients $(96.7 \%)$ did not receive such treatment. Table 3 presents data on the predisposing factors of MF. There were cases where one subject presented with more than one predisposing factor. The tropical climate and lack of hygiene were the mostly found predisposing factor of MF. The tropical climate, which is one of the predisposing factors of MF, was found in all samples regardless of the city of residence. Another predisposing factor was hygiene found in $73.3 \%$ of the case. There was a history of steroid use in one patient who was undergoing treatment for leprosy.

Not only carried out the clinical examination, but we also carried out other supporting examinations using Wood's lamp and direct examination using a microscope. Direct microscopic examination of stains was conducted to determine the formation of spores. The data are presented in Table 4. Thirty patients obtained positive Wood's lamp results with mostly $96.7 \%$ bright yellowish-green and 3.3\% bright blue fluorescence. The distribution of spore load on $\mathrm{KOH} 20 \%+$ Parker $^{\mathrm{TM}}$ Blue black ink was mostly found in grade $4+$, which was $63.3 \%$. There were $3(10 \%)$ negative results.

Table 1. Demographic data of research subjects

\begin{tabular}{|c|c|}
\hline Variables & $\begin{array}{l}\text { Patient } \\
(\mathrm{n}=30)\end{array}$ \\
\hline \multicolumn{2}{|l|}{ Sex } \\
\hline Male & $22(73.3)$ \\
\hline Female & $8(26.7)$ \\
\hline Age (year) & $23.67 \pm 7.14$ \\
\hline
\end{tabular}

Table 2. Characteristics of disease history of study subjects

\begin{tabular}{lcc}
\hline & Variable & Patient $(\mathrm{n}=30)$ \\
\hline Predilection & Face, back & 0 \\
& Face, back, chest & 0 \\
& Back & $9(30)$ \\
& Back, chest & $9(30)$ \\
& Back, chest, upper arm & $9(30)$ \\
& Back, upper arm & $3(10)$ \\
History of medication & & $1(3.3 \%)$ \\
& Yes & $29(96.7 \%)$ \\
\hline
\end{tabular}


Table 3. Distribution of predisposing factors that cause Malassezia Folliculitis.

\begin{tabular}{lc}
\multicolumn{1}{c}{ Predisposing factors } & Patient (\%) \\
\hline Living in a hot climate & $30(100)$ \\
The use of tight clothing & $8(26.7)$ \\
Poor hygiene & $22(73.3)$ \\
Use of oral or topical steroid & $1(3.3)$ \\
\hline
\end{tabular}

* One patient can have more than one predisposing factor

Table 4. Characteristics of supporting examinations

\begin{tabular}{|c|c|c|}
\hline Variable & $\begin{array}{c}\text { Frequency } \\
\quad \mathrm{N}=30\end{array}$ & Percentage (\%) \\
\hline \multicolumn{3}{|l|}{ Wood's Lamp } \\
\hline Bright yellowish-green & 29 & 96.7 \\
\hline White & 0 & 0 \\
\hline Bright blue & 1 & 3.3 \\
\hline Negative & 0 & 0 \\
\hline \multicolumn{3}{|c|}{$\mathrm{KOH} 20 \%+$ Parker $^{\mathrm{TM}}$ Blue black ink } \\
\hline Positive $(+)$ & 27 & 90 \\
\hline Negative (-) & 3 & 10 \\
\hline Precipitate $(+)$ & 18 & 60 \\
\hline \multicolumn{3}{|l|}{ Spore Load } \\
\hline Grade $1+$ & 0 & 0 \\
\hline Grade $2+$ & 0 & 0 \\
\hline Grade $3+$ & 8 & 26.7 \\
\hline Grade 4+ & 19 & 63.3 \\
\hline Negative & 3 & 10 \\
\hline \multicolumn{3}{|l|}{ MGG } \\
\hline Positive $(+)$ & 27 & 90 \\
\hline Negative (-) & 3 & 10 \\
\hline Precipitate $(+)$ & 0 & 0 \\
\hline \multicolumn{3}{|l|}{$\mathrm{KOH} 10 \%+\mathrm{CSB}$} \\
\hline Positive $(+)$ & 28 & 93.3 \\
\hline Negative (-) & 2 & 6.7 \\
\hline Precipitate $(+)$ & 5 & 16.7 \\
\hline
\end{tabular}

CSB: Chicago Sky Blue

$\mathrm{KOH}=$ Potassium Hydroxide

MGG $=$ May Grunwald Giemsa

The positivity was found in the $20 \% \mathrm{KOH}$ examination + Parker $^{\mathrm{TM}}$ Blue black ink in diagnosing MF at $90 \%$, and negative examination results in 3 patients $(10 \%)$. MGG staining provided similar results with $20 \% \mathrm{KOH}+$ Parker $^{\mathrm{TM}}$ Blue black ink, which were $90 \%$ positivity to spores, while a $10 \% \mathrm{KOH}+\mathrm{CSB}$ examination shows $93.3 \%$ positive results. There were 26 positive results on $20 \% \mathrm{KOH}+$ Parker $^{\mathrm{TM}}$ BlueBlack Ink and MGG, while there was 1 sample $(3.3 \%)$ that showed $20 \% \mathrm{KOH}$ results + negative Parker ${ }^{\mathrm{TM}}$ Blue-Black Ink with MGG results positive (Table 5). There were 28 positive results on $20 \% \mathrm{KOH}$ examination + Blue-Black Parker ${ }^{\mathrm{TM}}$ Ink and CSB, while there was 1 sample $(3.3 \%)$ that showed $20 \%$
$\mathrm{KOH}$ results + negative Blue-Black Parker ${ }^{\mathrm{TM}}$ Ink with CSB results positive (Table 6).

The data showed that there was no significant agreement between MGG and $\mathrm{KOH}+$ Parker-Blue Blue Black Ink and CSB and $\mathrm{KOH}+$ Parker-Blue Blue Black Ink $(\kappa=0.348, p=0.051(p=>0.05))$. The obtained CSB values were $96.3 \%$ sensitivity, $33.3 \%$ specificity, $92.9 \% \mathrm{PPV}$, and $50 \%$ NPV. The crosstabulation between MGG and CSB, the value of $\kappa$ $=1,000, \mathrm{p}=.000(<0.05)$ indicates that there was a significant agreement between $\mathrm{MGG}$ and $10 \% \mathrm{KOH}+$ CSB examination in evaluating spores in patients with MF (Table 7). 
Table 5. May Grunwald Giemsa and Potassium Hidroxide $20 \%+$ Blue-Black Parker ${ }^{\mathrm{TM}}$ Ink Crosstabulation

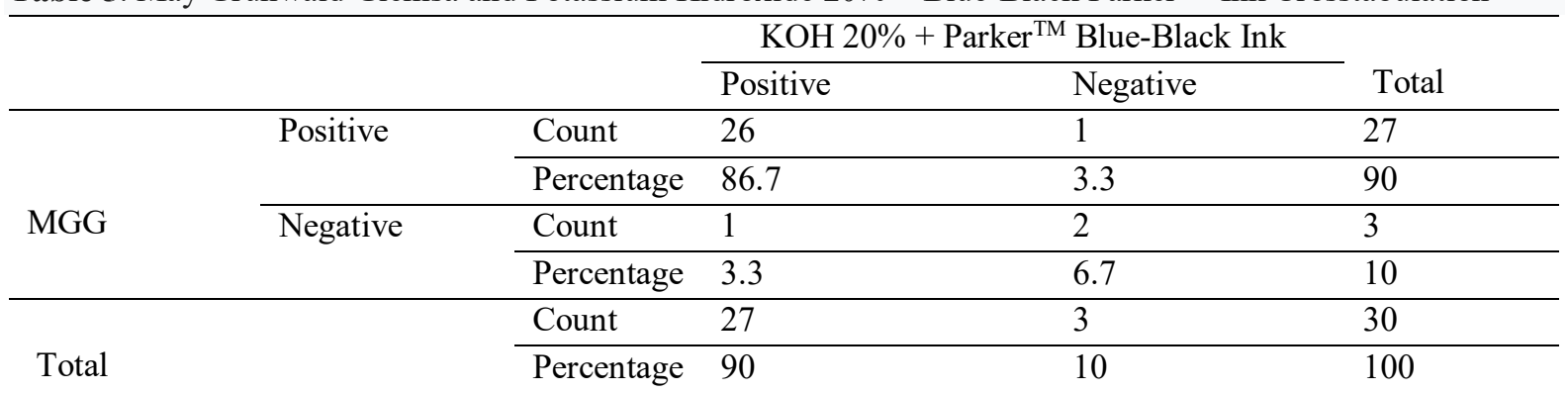

Kappa value, $\kappa=0.348, \mathrm{p}=0.051(>0.05)$

MGG = May Grunwald Giemsa

$\mathrm{KOH}=$ Potassium Hydroxide

Table 6. Crosstabulation of $10 \% \mathrm{KOH}+\mathrm{CSB}$ and $\mathrm{KOH}+$ Blue-Black ParkerTM Ink

\begin{tabular}{|c|c|c|c|c|c|}
\hline & \multicolumn{2}{|c|}{$\mathrm{KOH}+$ Parker $^{\mathrm{TM}}$ Blue-Black Ink } & \multirow[b]{2}{*}{ Total } \\
\hline & & & Positive & Negative & \\
\hline \multirow{4}{*}{$\mathrm{KOH} 10 \%+\mathrm{CSB}$} & \multirow[t]{2}{*}{ Positive } & Count & 26 & 2 & 28 \\
\hline & & Percentage & 86.7 & 6.7 & 93.4 \\
\hline & \multirow[t]{2}{*}{ Negative } & Count & 1 & 1 & 2 \\
\hline & & Percentage & 3.3 & 3.3 & 6.6 \\
\hline \multirow[b]{2}{*}{ Total } & & Count & 27 & 3 & 30 \\
\hline & & Percentage & 90 & 10 & 100 \\
\hline
\end{tabular}

Kappa value, $\kappa=0.348, p=0.051(>0.05)$

$\mathrm{KOH}=$ Potassium Hydroxide

$\mathrm{CSB}=$ Chicago Sky Blue

Table 7. Crosstabulation of $10 \% \mathrm{KOH}+\mathrm{CSB}$ and $\mathrm{MGG}$

\begin{tabular}{|c|c|c|c|c|c|}
\hline & & & & $\overline{\mathrm{GG}}$ & \\
\hline & & & Positive & Negative & Total \\
\hline & Positive & Count & 28 & 0 & 28 \\
\hline & & Percentage & 93.3 & 0 & 93.3 \\
\hline $\mathrm{KOH} 10 \%+\mathrm{CSB}$ & Negative & Count & 0 & 2 & 2 \\
\hline & & Percentage & 0 & 6.7 & 6.7 \\
\hline & & Count & 28 & 2 & 30 \\
\hline Total & & Percentage & 93.3 & 6.6 & 100 \\
\hline
\end{tabular}

$\mathrm{KOH}=$ Potassium Hydroxide

$\mathrm{CSB}=$ Chicago Sky Blue

$\mathrm{MGG}=$ May Grunwald Giemsa

\section{DISCUSSION}

There were $22(73.3 \%)$, male patients, out of 30 total patients. The results were in line with a research by Ariyanti P. conducted in the Mycology Division of Dermatology and Venereology outpatient clinic of Dr. Soetomo general hospital Surabaya. The research found that there were more male MF patients than female MF patients. ${ }^{11}$ Another study conducted by Sharquie et al. in Iraq comparing MF with truncal acne found that $62.3 \%$ of MF patients were male, and the mean of age was $28.88 \pm 5.3$ years. $^{7}$

A higher number of male MF patients might be related to believe that males have more active physical activity, making them sweat; therefore, more susceptible to fungal infections. Research by Lim in Singapore also confirmed the higher MF incidence in males than females. This illustrates that high androgen levels may be a predisposing factor as it can stimulate sebaceous gland activity and increase sebum production. ${ }^{12}$ The average age in this study was 23.67 \pm 7.14 years, and the highest incidence was in the age range of 17-25 years. This was also consistent with research conducted by Tsai YC et al. in China. The research found that $77 \%$ of patients with MF diagnosis were predominantly males with an average age of 1435 years. ${ }^{13}$

Pravitasari DW et al. stated that the highest MF incidence was in 15-24 years age group. ${ }^{6}$ Research by 
Purnak et al. also showed a similar result on the highest MF incidence, which was $22.8 \pm 6.8$ years. According to the Ministry of Health of the Republic of Indonesia, persons aged 15-24 years old are categorized as adolescents. During the adolescent period, there is an increase in sebaceous gland activity, which will subsequently promote fungal colonization.

Hot and humid weather conditions are the triggering factors of MF. The finding was consistent with research by Sharquie et al., confirming that $58 \%$ of hot and humid weather triggers MF. ${ }^{7}$ Another research also confirmed that MF generally appears in hot environments, humid climates and often sweaty conditions. ${ }^{14}$ Hot conditions can encourage the flow of sebum to the skin surface, causing sebum accumulation; therefore, promoting Malassezia to grow. ${ }^{8}$

Clinical predilection of MF is very typical. The most frequent locations complained by subjects were the back, chest, and upper arms area by $30 \%$. A study by Suzuki C in Japan, involving 44 samples, found that $60 \%$ of MF patients had lesions in the chests. ${ }^{16}$ Another study stated that upper body parts such as the back, chest, and upper arms are the most common sites. It is rare for MF to occur on the face. The rarity of MF cases on the face is most likely due to regular face wash, reducing the existing sebum on the face. ${ }^{13}$ It has been reported that in more than $90 \%$ of healthy individuals, the percentage of pityrosporum in the interscapular area is higher; therefore, MF predilection is more frequent in the middle of the back. ${ }^{7}$

Several factors can trigger the occurrence of MF. This study found that living in a tropical climate is one of the leading factors that can cause MF. Hot weather can increase the rate of sebum secretion to the surface of the skin, and sebum accumulation due to increased secretion rate is a good growth media for fungi. The second leading factor is poor hygiene. Our study found that most MF patients had poor hygiene that they rarely take a bath after sweaty activities. ${ }^{2}$

Several investigations are available for MF diagnosis. Wood's lamp is one of the MF diagnostic tools, which functions by irradiating the suspected lesions. The lesions should then illuminate yellowishgreen, bright, bright blue, or white fluorescence. This study found that most samples $(29.7 \%)$ showed a bright yellowish-green color. This was consistent with the research conducted by Sharquie et al. that found all samples showed bright yellowish-green color. ${ }^{7}$ Durdu et al. also found that $66.7 \%$ of Wood's lamp results illuminated bright yellowish-green color. ${ }^{14}$

Research on staining comparison between MGG and $\mathrm{KOH} 10 \%+\mathrm{CSB}$ in MF patients is still limited. The agreement between the three stainings, namely
$20 \% \mathrm{KOH}+$ Parker $^{\mathrm{TM}}$ Blue-Black Ink, MGG, and 10\% $\mathrm{KOH}+\mathrm{CSB}$, were processed using crosstabulation to determine the suitability on spore readings and to calculate the required sensitivity, specificity, Positive Predictive Value (PPV), and Negative Predictive Value (NPV) of patients with MF clinical features. The crosstabulation results showed no significant agreement between $\mathrm{MGG}$ and $20 \% \mathrm{KOH}+$ Parker $^{\mathrm{TM}}$ Blue-Black Ink and $10 \% \mathrm{KOH}+\mathrm{CSB}$ and $20 \% \mathrm{KOH}$ + Blue Black ParkerTM Ink $(\kappa=0.348, \mathrm{p}=0.051)$ with 96.3\% sensitivity, 33.3\% specificity, 92.9\% PPV, and $50 \%$ NPV. Results of MGG and KOH $10 \%+$ CSB were supported by the crosstabulation between MGG and $\mathrm{KOH} 10 \%+\mathrm{CSB}$ obtained $\kappa=1,000, \mathrm{p}=.000$ $(<0.05)$, indicating that there was a significant conformity of $\mathrm{MGG}$ and $\mathrm{KOH} 10 \%+\mathrm{CSB}$ in examining spores in MF patients.

The research concluded that there was no significant agreement between MGG and $\mathrm{KOH} \mathrm{10 \% +}$ $\mathrm{CSB}$ and $\mathrm{KOH}+$ Parker $^{\mathrm{TM}}$ Blue-Black Ink in establishing MF diagnosis. MF diagnostic tests using MGG and $\mathrm{KOH} 10 \%+\mathrm{CSB}$ both have $96.6 \%$ sensitivity, 33.3\% specificity, 92.9\% PPV, and 50\% NPV.

Both stainings have particular advantages and disadvantages. The advantage of MGG staining is that the preparations can be stored and used for a longer time. The weakness of Giemsa as one of the MGG reagents is that it gets dirty easily and fragile. For a better result, Giemsa needs to be filtered using a paper filter. MGG staining requires a longer staining process compared to CSB. The advantage of $10 \% \mathrm{KOH}+\mathrm{CSB}$ staining is the ease of use. to do as in $20 \% \mathrm{KOH}+$ blueblack Parker ${ }^{\mathrm{TM}}$ ink that is only dripped. This research found precipitates on $10 \% \mathrm{KOH}+\mathrm{CSB}$ staining, but these precipitates did not interfere with the appearance of spores. This coloring can also be clarified with a 1000x magnification.

As that there was no significant difference between MGG and $\mathrm{KOH} 10 \%+\mathrm{CSB}$ and $20 \% \mathrm{KOH}+$ Parker $^{\mathrm{TM}}$ Blue-Black Ink in MF diagnosis. The 20\% $\mathrm{KOH}+$ Blue Parker Black ink staining remains necessary as a routine examination for MF cases because it is more practical, easy, inexpensive, and fast. Further research using microscopic examination is recommended with more than one medical analyst (with an odd number) for a better examination.

\section{REFERENCES}

1. PERDOSKI. Panduan Praktik klinis. In : Widaty S, Soebono H, Nilasari H, Listiawan MY, Siswati AS, Triwahyudi D, Editors. Jakarta. Sekretaria PP PERDOSKI. 2017. p. 101-3. 
The Concordance of Three Diagnostic Test for Malassezia folliculitis

2. Miranda E. Malassezia folliculitis. In: Bramono K, Suyoso S, Indriatmi W, Ramali LM, Widaty S, Ervianti E, editor. Dermatomikosis superfisialis. Edisi ke-2. Jakarta: Badan Penerbit FKUI. 2013. p. 35-40.

3. Craft N. Superficial cutaneous infections and pyodermas. In: Goldsmith L.A, Katz S.I, Gilchrest BA, Paller AS, Leffell DJ, Wolf K, editors. Fitzpatrick'sdermatology in the general medicine. $8^{\text {th }}$ ed. New York: The McGraw-Hill Companies Inc. 2012. p. 2128-47.

4. Hay RJ, Ashbee HR. Fungal Infection : Malassezia folliculitis. In: Griffiths C, Barker J, Bleiker T, Chalmers R, Creamer D, editors. Rook's Textbook of Dermatology. 9th ed. Volume 1. United Kingdom: John Wiley \& Sons, Ltd. 2016. p. 3213-15.

5. Kundu RV, Garg A. Yeast Infection : Candidiasis, Tinea (Pityriasis Versicolor), and Malassezia (Pityriasis) Folicullitis. In: Wolff K, Goldsmith LA, Katz SI, Gilchrest BA, Paller AS, Leffell DJ, editors. Fitzpatricks's Dermatology in General Medicine. 8th ed. New York: The McGraw-Hill Companies. 2012. p. 2298-311.

6. Pravitasari DN, Suyoso S, Ervianti E. Profil Malassezia Folliculitis. Berkala Ilmu Kesehatan Kulit Kelamin 2015;27(2): 121-9.

7. Velegraki A, Cafarchia C, Gaitanis G, Latta R, Boekhout T. Malassezia Infections in humans and animals: pathophysiology, detection, and treatment. Plos Pathog 2015; 11(1): 1-6.

8. Rubenstein RM, Malerich SA. Case report and literature review: Malassezia (Pityrosporum) Folliculitis. J Clin Aesthet Dermatol 2014; 7(3): p. 37-41.

9. Prindaville B, Belazarian L, Levin NA, Wiss K. Pityrosporum folliculitis: a retrospective review of 110 cases. J Am Acad Dermatol 2017; 2: 1-16.

10. Al Hawsawi K, Altalhi S, Alwafi D, Aldosari M. Pityrosporum folliculitis: a case report. Dermatol Open J 2019; 3(1): 17-18.

11. Ariyanti P, Hidayati AN, Suyoso S. Perbandingan pemeriksaan May Grunwald Giemsa (MGG) dan Potassium Hidroxide (KOH) pada pasien Malassezia folliculitis di Unit Rawat Jalan Kesehatan Kulit dan Kelamin Dr. Soetomo General Hospital Surabaya. Berkala Ilmu Kesehatan Kulit Kelamin 2017; 29(3): 195-203.
12. Thayikkannu AB, Kindo AJ, Veearaghavan $M$. Malassezia-Can it be Ignored ?. Indian J Dermatol 2015; 60(4): 332-39.

13. Tsai YC, Wang JY,Wu YH, Wang YJ. Clinical Differences in Pediatric and Adult Malassezia Folliculitis: retrospective analysis of 321 cases over 9 years. J Am Acad Dermatol 2019; 81(1): 278-80.

14. Durdu M, Guran M, Ilkit M. Epidemiological characteristics of Malassezia folliculitis and use of the May-Grünwald-Giemsa stain to diagnose the Infection. Diagnosis in Microbiology Infection Disease 2013; 76: 450-7.

15. Purnak S, Durdu M, Tekindal MA, Gulec TA et al. The Prevalence of malassezia folliculitis in patients with papulopustular/comedonal acne, and their response to antifungal treatment. Skinmed 2018; 16: 99-104.

16. Suzuki C, Hase M, Shimoyama H, Sei Y. Treatment Outcomes for Malassezia Folliculitis in The Dermatology Department of a University Hospital in Japan. Med Mycol J 2016; 57(3): E636.

17. Piotr B, Danuta K. Malassezia folliculitis on the neck. N Dermatol 2010; 1(2): 22-5.

18. Horobin RW. Dis-, tris- and polyazo dyes. Dalam: Horobin RW, Kiernan J. Conn's biological stains: A handbook of dyes, stains and fluorochromes for use in biology and medicine. 10th ed. Oxford, UK: BIOS Scientific Publishers 2002. p. 125-44.

19. Argentina F, Rusmawardiana, Thaha MA, Tjekyan RMS. Nilai Diagnostik Larutan Chicago Sky Blue pada Pityriasis versikolor di RSUP Dr. Mohammad Hoesin Palembang. MDVI 2016; 43(1): 17-24.

20. Noviandini A, Suyoso S, Astari L. Pemeriksaan pewarnaan kalium hidroksida $(\mathrm{KOH}) 20 \%$ tinta Parker $^{\mathrm{TM}}$ blue black, chicago sky blue (CSB), dan kultur jamur di Divisi Dermatomikologi Unit Rawat Jalan Kesehatan Kulit dan Kelamin Dr. Soetomo General Hospital Surabaya. Berkala Ilmu Kesehatan Kulit Kelamin 2017; 29(1): 21-9. 